\title{
INFLUENCE OF DIFFERENT SOIL SUBSTRATES, PLANTING TIME AND STEM CUTTINGS TYPE ON VEGETATIVE PROPAGATION AND GROWTH CHARACTERISTICS OF VITEX AGNUS-CASTUS L. VPLYV RÔZNYCH PÔDNYCH SUBSTRÁTOV, ČASU VÝSADBY A TYPOV STONKOVÝCH ODREZKOV NA VEGETATÍVNE ROZMNOŽOVANIE A RASTOVÉ VLASTNOSTI VITEX AGNUS-CASTUS L.
}

\author{
Maryam I. S. ALKURDI, ', Sabiha S. MUSTAFA, ${ }^{2}$ Ján SUPUKA ${ }^{1}$ \\ Slovak University of Agriculture in Nitra, Slovak Republic ${ }^{1}$ \\ Agriculture College Salahaddin University, Iraq Kurdistan Region-Erbil ${ }^{2}$
}

\begin{abstract}
The study of vegetative propagation of the Vitex agnus-castus L., was conducted in the Agriculture College - Salahaddin University field under controlled condition (plastic greenhouse) in two periods (summer time: from 26.5.2008 to 2.9.2008 and winter time: from 15.1.2009 to 28.4.2009). The object of the studies were different soil substrates (sand and river (sharp) sand - sand and peat moss - sand and river (sharp) sand and peat moss). We used two types of stem cuttings (semi-hardwood cuttings "m" softwood cuttings ${ }_{\text {, }} \mathrm{a}^{\prime \prime}$ ). The statistical analysis is based on the experimental project Complete Randomized Design (CRD) with three replications. The results were compared with results from Duncan test at 0.05 level. The study showed that planting in the second period (T2) causes increase in number of branches and leaves, whereas planting in the first period (T1) causes increase in number of roots and root length, the increase in the weight of biomass and dry mass has been observed in the second period of planting (T2). Planting in the sand substrate using semi-hardwood cuttings $(\mathrm{m})$ causes increase in number of branches, leaves, fresh weight, number of roots and root length.
\end{abstract}

Keywords: Vitex agnus-castus, propagation, cuttings, soil substrates

Vitex agnus-castus L. belongs to the Verbenaceae family, native to the Mediterranean and Central Asia. The fruit has a spicy pepper like aroma and taste. The dried ripe fruits are used medicinally (Sima et al., 2007). Vitex is an excellent choice for a large shrub or small flowering tree in a smaller modern suburban landscape. The blossoms of Vitex emerge from May to September. The aromatic leaves are palmate, with five to seven leaflets. All deadwood and lower branches may be removed from the shrubs in winter time. Propagation by cuttings takes place in the summer or winter. Lower branches may be layered by burying in the soil. There are sometimes also volunteer seedlings that may be transplanted elsewhere in the garden. Vitex grows best in full sun, in a variety of soils, provided they are well drained (Welch, 2008).

Cuttings are probably the most important method for starting new plants. A cutting is any detached plant part which, under favorable conditions for regeneration, will produce a new plant identical to the parent plant (Mohyeldeen, 2009). The period of the year when cuttings are collected is one of the most important factors controlling the success of rooting. Some cuttings, like Forsythia, can be rooted at almost any time of the year while others will only be successful during two to three month-long periods (Wells, 1985). The media should be well drained and yet retain sufficient water to reduce the frequency of watering. Other parameters to consider include costs, availability, and consistency between batches and stability in the media overtime. Selection of the proper media components is crucial for a successful production of plants (Robbins and Evans, 2009).The main objectives of this study are to investigate the propagation of Vitex agnus-castus L. by using stem cuttings, and to determine the suitable time for planting using the different soil substrates.

\section{Material and methods}

To study the effects of the propagation media on the rate of growth of Vitex agnus-castus, a study was carried out in the plastic greenhouse at the Salahaddin University in Erbil in two periods during T1 (from 26. 5. 2008 to 2. 9. 2008) and T2 (from 15. 1. 2009 to 28. 4. 2009).

The rooting substrates were composed primarily of sand, particles from $2 \mathrm{~mm}$ to $0.06 \mathrm{~mm}(\mathrm{~S})$; sand and river (sharp) sand, particles from $0.425 \mathrm{~mm}$ to $0.075 \mathrm{~mm}$ (sz) at ratio $1: 1$; sand mixed with peat moss (sp) at ratio $1: 1$ and sand with river (sharp) sand with peat moss (szp) at ratio $1: 1: 1$. Two types of stem cuttings were taken from nursery stock plants (soft stem cuttings (a) and semi-hardwood stem cuttings $(\mathrm{m})$. grown in polyethylene bags $20 \times 30 \mathrm{~cm})$. The cuttings were taken from the medium and basal parts of the main branches of mature plants. They were about $25-30 \mathrm{~cm}$ in length. All the cuttings were treated with fungicide (Ridomil). The plants were irrigated daily with fresh water. The experiment was laid out in Complete Randomized Design (CRD) with tree replications and the treatments were tested by Duncan test under level of significance 0.05 (Alrawi and Khalaf, 1980). The following phenological characters have been measured: 
1. Number of branches.

2. The average length of shoots.

3. The average number of leaves

4. The average length of roots $(\mathrm{cm})$

5. Fresh weight of roots (g).

6. The average number of roots $(\mathrm{cm})$.

7. Fresh weight of shoots $(\mathrm{g})$.

8. Dry weight of shoots (g).

9. Dry weight of roots $(\mathrm{g})$.

\section{Results and discussion}

As seen in the Table 1, the planting time significantly affects the number of branches (T2) affected the number of branches in more significant way compared to (T1), planting in the (T2) led to increase in the number of leaves compared to (T1) and the difference was significant, while planting in (T1) led to increased root numbers and root length compared to (T2). These results agree with Elgimabi (2008) who proved that (T1) led to an increase in the number of roots and root length compared to (T2) in Ixora coccinea.
Whereas increased fresh weight and dry weight of shoots was detected significantly in the (T2) and this agrees with Mahfoud and Makhoul (2006) who proved that (T2) caused the highest percentage of rooting compared to (T1) in kiwi fruit. The fresh weight of roots has increased in (T1), while the dry weight of roots was not affected by the date of planting.

Table 2 shows that planting in sand media (s) using semihardwood cuttings $(\mathrm{m})$ led to an increase in the number of branches and the highest percentage compared to other treatments and differences which agrees with Alkutub et al. (1997). They stated that this is more advisable media for Jasminum officinalis. Perhaps because of the absence of sand microbiological activity which is typical for good ventilation. As if they were getting larger number of leaves when planted in the sand using mind wooden half and the difference was significant compared to the soil mixture (sand peat moss and sand agricultural = sand agricultural peat moss) with the use of reason is soft, perhaps because containment this mixture on the excess moisture and persistent even be a good compromise for the proliferation of micro organisms responsible for microbial degradation of organic matter and this is what is causing adverse effects

$\begin{array}{lll}\text { Table } 1 & \text { Effect of planting date on studied characteristics of Vitex agnus-castus L. }\end{array}$

\begin{tabular}{|c|c|c|c|c|c|c|c|c|c|}
\hline \multirow{2}{*}{$\begin{array}{l}\text { Planting } \\
\text { time (2) }\end{array}$} & \multicolumn{9}{|c|}{ Studied characteristics (1) } \\
\hline & $\begin{array}{c}\text { number of } \\
\text { branches } \\
\text { (3) (pc) }\end{array}$ & $\begin{array}{l}\text { average } \\
\text { number of } \\
\text { leaves (4) } \\
\text { (pc) }\end{array}$ & $\begin{array}{l}\text { average } \\
\text { length of } \\
\text { shoots (5) } \\
\text { in } \mathrm{cm}\end{array}$ & $\begin{array}{c}\text { number } \\
\text { of roots (6) } \\
\text { (pc) }\end{array}$ & $\begin{array}{l}\text { average } \\
\text { length of } \\
\text { roots (7) } \\
\text { in } \mathrm{cm}\end{array}$ & $\begin{array}{c}\text { fresh } \\
\text { weight of } \\
\text { shoots (8) } \\
\text { in } \mathrm{g}\end{array}$ & $\begin{array}{c}\text { fresh } \\
\text { weight of } \\
\text { roots (9) in g }\end{array}$ & $\begin{array}{l}\text { dry weight } \\
\text { of shoots } \\
(10) \text { in } g\end{array}$ & $\begin{array}{l}\text { dry weight } \\
\text { of roots (11) } \\
\text { in } \mathrm{g}\end{array}$ \\
\hline$(\mathrm{T} 2)$ & \multirow{2}{*}{ a3.01 } & \multirow{2}{*}{ a13.98 } & \multirow{2}{*}{ b3.70 } & \multirow{2}{*}{ b2.46 } & \multirow{2}{*}{ a6.36 } & \multirow{2}{*}{ a15.76 } & \multirow{2}{*}{ b0.23 } & \multirow{2}{*}{ a8.46 } & \multirow{2}{*}{$\mathrm{a} 0.12$} \\
\hline $5 / 1 / 2009$ & & & & & & & & & \\
\hline$(\mathrm{T} 1)$ & \multirow{2}{*}{ b2.08 } & \multirow{2}{*}{ b10.29 } & \multirow{2}{*}{ a6.94 } & \multirow{2}{*}{ a4.04 } & \multirow{2}{*}{ a7.12 } & \multirow{2}{*}{ b1.96 } & \multirow{2}{*}{$\mathrm{a} 0.50$} & \multirow{2}{*}{ b0.83 } & \multirow{2}{*}{$\mathrm{a} 0.23$} \\
\hline $26 / 5 / 2008$ & & & & & & & & & \\
\hline
\end{tabular}

Tabulka 1 Vplyv dátumu výsadby na pozorované charakteristické vlastnosti Vitex agnus-castus L.

(1) pozorované charakteristické vlastnosti, (2) čas výsadby, (3) počet vetiev (pc), (4) priemerný počet listov (pc), (5) priemerná dlí̌ka výhonkov $v \mathrm{~cm}$, (6) počet koreňov ( $\mathrm{pc}$ ), (7) priemerná dlžka koreňov $\mathrm{v} \mathrm{cm}$, (8) čerstvá hmotnost' výhonkov v g, (9) čerstvá hmotnost' koreňov v g, (10) suchá hmotnost' výhonkov in g, (11) suchá hmotnost’ koreňov v g

Table 2 Effect of different soil substrate mixtures and cuttings types on studied characteristics Vitex agnus-castus L.

\begin{tabular}{|l||c|c|c|c|c|c|c|c|c|}
\hline \multirow{2}{*}{$\begin{array}{l}\text { Soil sub- } \\
\text { strates + } \\
\text { cuttings } \\
\text { type (2) }\end{array}$} & $\begin{array}{c}\text { number of } \\
\text { branches (3) } \\
\text { (pc) }\end{array}$ & $\begin{array}{c}\text { average } \\
\text { number } \\
\text { of foliage } \\
\text { (4) (pc) }\end{array}$ & $\begin{array}{c}\text { average } \\
\text { length of } \\
\text { shoots (5) } \\
\text { in cm }\end{array}$ & $\begin{array}{c}\text { number of } \\
\text { roots (6) } \\
\text { (pc) }\end{array}$ & $\begin{array}{c}\text { average } \\
\text { length of } \\
\text { roots (7) } \\
\text { in cm }\end{array}$ & $\begin{array}{c}\text { fresh } \\
\text { weight of } \\
\text { shoots (8) } \\
\text { in g }\end{array}$ & $\begin{array}{c}\text { fresh } \\
\text { weight of } \\
\text { roots (9) } \\
\text { in g }\end{array}$ & $\begin{array}{c}\text { dry weight } \\
\text { of shoots } \\
\text { (10) } \\
\text { in g }\end{array}$ & $\begin{array}{c}\text { dry weight } \\
\text { of roots } \\
\text { (11)in g }\end{array}$ \\
\hline $\mathrm{S}+\mathrm{m}$ & $\mathrm{a} 4$ & $\mathrm{a} 18.77$ & $\mathrm{a} 14.43$ & $\mathrm{ab} 5.67$ & $\mathrm{a} 16.92$ & $\mathrm{a} 13.67$ & $\mathrm{a} 0.71$ & $\mathrm{a} 6.69$ & $\mathrm{a} 0.21$ \\
\hline $\mathrm{sp}+\mathrm{m}$ & $\mathrm{ab} 3.33$ & $\mathrm{a} 18.10$ & $\mathrm{~b} 8.13$ & $\mathrm{bc} 4.17$ & $\mathrm{ab} 13.32$ & $\mathrm{a} 12.32$ & $\mathrm{ab} 0.57$ & $\mathrm{a} 6.46$ & $\mathrm{a} 0.33$ \\
\hline $\mathrm{szp}+\mathrm{m}$ & $\mathrm{ab} 3.30$ & $\mathrm{a} 15.93$ & $\mathrm{~b} 4.75$ & $\mathrm{a} 7.58$ & $\mathrm{cb} 9.58$ & $\mathrm{a} 12.29$ & $\mathrm{abc0.54}$ & $\mathrm{a} 6.34$ & $\mathrm{ab} 0.30$ \\
\hline $\mathrm{Sz}+\mathrm{m}$ & $\mathrm{ab} 3.15$ & $\mathrm{a} 16.87$ & $\mathrm{~b} 7.88$ & $\mathrm{bcd} 2.67$ & $\mathrm{~cd} 5.80$ & $\mathrm{a} 12.82$ & $\mathrm{abcd} 0.37$ & $\mathrm{a} 6.39$ & $\mathrm{ab} 0.21$ \\
\hline $\mathrm{szp}+\mathrm{a}$ & $\mathrm{bc} 2.35$ & $\mathrm{~b} 9.00$ & $\mathrm{c} 2.07$ & $\mathrm{bd} 2.50$ & $\mathrm{~d} 2.75$ & $\mathrm{~b} 5.78$ & $\mathrm{bcd} 0.21$ & $\mathrm{~b} 3.81$ & $\mathrm{ab} 0.17$ \\
\hline $\mathrm{sp}+\mathrm{a}$ & $\mathrm{c} 1.57$ & $\mathrm{~b} 6.5$ & $\mathrm{c} 1.27$ & $\mathrm{~cd} 1.67$ & $\mathrm{~d} 1.30$ & $\mathrm{~b} 4.22$ & $\mathrm{abcd} 0.43$ & $\mathrm{~b} 2.46$ & $\mathrm{ab} 0.09$ \\
\hline $\mathrm{Sz}+\mathrm{a}$ & $\mathrm{c} 1.42$ & $\mathrm{~b} 5.97$ & $\mathrm{c} 2.35$ & $\mathrm{~d} 0.58$ & $\mathrm{~d} 2.50$ & $\mathrm{~b} 4.68$ & $\mathrm{~cd} 0.07$ & $\mathrm{~b} 2.45$ & $\mathrm{~b} 0.03$ \\
\hline $\mathrm{S}+\mathrm{a}$ & $\mathrm{c} 1.27$ & $\mathrm{~b} 5.93$ & $\mathrm{c} 1.27$ & $\mathrm{~cd} 1.17$ & $\mathrm{~d} 1.75$ & $\mathrm{~b} 4.87$ & $\mathrm{~d} 0.05$ & $\mathrm{~b} 2.48$ & $\mathrm{~b} 0.01$ \\
\hline
\end{tabular}

Tabulka 2 Vplyv rozličných zmesí pôdnych substrátov a typov odrezkov na pozorované charakteristické vlastnosti Vitex agnus-castus L.

(1) pozorované charakteristické vlastnosti, (2) pôdne substráty + typy odrezkov, (3) počet vetiev (pc), (4) priemerný počet listov

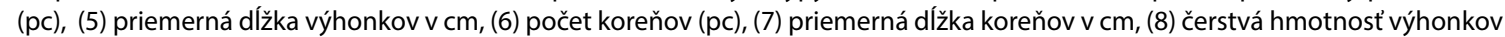
$\vee \mathrm{g}$, (9) čerstvá hmotnost' koreňov v g, (10) suchá hmotnost' výhonkov v $\mathrm{g}$, (11) suchá hmotnost' koreňov v g 
Table 3 Effect of interaction between planting time, soil substrate mixtures and cuttings types on studied characteristics Vitex agnus-castus L.

\begin{tabular}{|c|c|c|c|c|c|c|c|c|c|}
\hline \multirow{2}{*}{$\begin{array}{l}\text { Planting } \\
\text { time, cuttings } \\
\text { type and soil } \\
\text { substrates (2) }\end{array}$} & \multicolumn{9}{|c|}{ Studied characteristics (1) } \\
\hline & $\begin{array}{c}\text { number of } \\
\text { branches } \\
(3)(p c)\end{array}$ & $\begin{array}{c}\text { average } \\
\text { number of } \\
\text { leaves (4) } \\
\text { (pc) } \\
\end{array}$ & $\begin{array}{c}\text { average } \\
\text { length of } \\
\text { shoots (5) } \\
\text { in } \mathrm{cm} \\
\end{array}$ & $\begin{array}{l}\text { number of } \\
\text { roots (6) } \\
\text { (pc) }\end{array}$ & \begin{tabular}{|c|} 
average \\
length of \\
roots (7) in \\
$\mathrm{cm}$ \\
\end{tabular} & $\begin{array}{c}\text { Fresh } \\
\text { weight of } \\
\text { shoots (8) } \\
\text { in } \mathrm{g} \\
\end{array}$ & $\begin{array}{l}\text { fresh } \\
\text { weight of } \\
\text { roots (9) } \\
\text { in } \mathrm{g}\end{array}$ & $\begin{array}{c}\text { dry weight } \\
\text { of shoots } \\
(10) \text { in } g\end{array}$ & $\begin{array}{c}\text { dry weight } \\
\text { of roots (11) } \\
\text { in } \mathrm{g}\end{array}$ \\
\hline$(\mathrm{T} 2)$ & \multirow{2}{*}{ a4.00 } & \multirow{2}{*}{ a20.53 } & \multirow{2}{*}{ bcd6.10 } & \multirow{2}{*}{ bc4.67 } & \multirow{2}{*}{ b17.13 } & \multirow{2}{*}{ a22.83 } & \multirow{2}{*}{$\mathrm{abc0} 0.43$} & \multirow{2}{*}{ a12.33 } & \multirow{2}{*}{ ab0.18 } \\
\hline$S p+m$ & & & & & & & & & \\
\hline$(\mathrm{T} 1)$ & \multirow{2}{*}{ a4.00 } & \multirow{2}{*}{ a20.67 } & \multirow{2}{*}{ a23.67 } & \multirow{2}{*}{ b7.00 } & \multirow{2}{*}{ a26.50 } & \multirow{2}{*}{ bc6.86 } & \multirow{2}{*}{ a1.13 } & \multirow{2}{*}{$\mathrm{cd} 2.68$} & \multirow{2}{*}{ ab0.31 } \\
\hline $\mathrm{S}+\mathrm{m}$ & & & & & & & & & \\
\hline$(\mathrm{T} 2)$ & \multirow{2}{*}{$\mathrm{a} 4.00$} & \multirow{2}{*}{$\mathrm{abc16.87}$} & \multirow{2}{*}{ bcd5.20 } & \multirow{2}{*}{ bc4.33 } & \multirow{2}{*}{ c7.33 } & \multirow{2}{*}{ a20.87 } & \multirow{2}{*}{ bc0.28 } & \multirow{2}{*}{ a10.70 } & \multirow{2}{*}{ ab0.11 } \\
\hline$S+m$ & & & & & & & & & \\
\hline (T2) & 0362 & $3 \mathrm{be} 16 \wedge 0$ & bods on & 6167 & 6650 & & ben 30 & 11157 & shonos \\
\hline $\mathrm{Sz}+\mathrm{m}$ & as.63 & $\mathrm{abc} 10.40$ & DCO4.80 & Cl.6/ & c0.50 & aLL.s/ & DCO.30 & all.s & abu.uy \\
\hline$(\mathrm{T} 1)$ & 23.32 & 961767 & hods 10 & 11167 & bce 67 & d1 81 & abco 18 & dn 83 & 20 \\
\hline $\mathrm{Szp}+\mathrm{m}$ & a3.33 & abl. & Dcd4.40 & all.o/ & DC8.6/ & d1.81 & abcu.48 & edu.83 & abu. 28 \\
\hline$(\mathrm{T} 2)$ & & & & & & & & & \\
\hline Szp + m & a3.21 & $\mathrm{abc} 14.20$ & bcds. 10 & bc3.50 & bc10.50 & a22.// & $\mathrm{abc0} .60$ & a11.8/ & ab0.32 \\
\hline$(\mathrm{T} 1)$ & 26266 & & & & & & & & \\
\hline$S p+m$ & ab 2.06 & abc15.6/ & bc10.1/ & bc3.6/ & bc9.50 & d1.81 & abc0.69 & ed0.59 & a0.48 \\
\hline$(\mathrm{T} 1)$ & & & & & & & & & \\
\hline $\mathrm{Sz}+\mathrm{m}$ & ab2.66 & $\mathrm{abc1} 1.33$ & b10.93 & bc3.6/ & c5.10 & cd3.0/ & $\mathrm{abc0} .44$ & ed1.23 & ab0.33 \\
\hline (T2) & ab2.53 & bcd11.87 & $\operatorname{cd} 3.37$ & $c 2.00$ & $c 3.50$ & b9.73 & $c 0.06$ & bC4.97 & b0.02 \\
\hline$(\mathrm{T} 2)$ & & & & & & & & & \\
\hline Szp $+a$ & ab2.37 & bcd12.33 & d1.63 & c0.33 & c0.17 & b10.17 & c0.17 & b6.84 & ab0.07 \\
\hline$(\mathrm{T} 1)$ & ab2.33 & def5.67 & $\mathrm{d} 2.50$ & bc4.67 & c5.33 & d1.39 & bc0.41 & ed0.77 & ab0.27 \\
\hline (T2) & & & & & & & & & \\
\hline $\mathrm{Sz}+\mathrm{a}$ & ab2.1/ & bcde10.27 & d1.6/ & c1.1/ & c5.00 & b9.33 & bC0.13 & bC4./3 & ab0.05 \\
\hline$(\mathrm{T} 2)$ & & & & & & & & & \\
\hline $\mathrm{Sp}+\mathrm{a}$ & ab2.13 & cde9.33 & d1./0 & $C 2.00$ & c0.// & b/.// & C0.03 & bC4.54 & b0.01 \\
\hline $\begin{array}{l}(\mathrm{T} 1) \\
\mathrm{sp}+\mathrm{a}\end{array}$ & bc1.00 & ef3.67 & d0.83 & c1.33 & C1.83 & d0.67 & ab0.87 & ed0.37 & ab0.17 \\
\hline (T1) & & & & & & & & & \\
\hline $\mathrm{Sz}+\mathrm{a}$ & bc0.67 & f1.67 & d3.03 & c0.00 & c0.00 & d0.03 & c0.00 & e0.17 & b0.00 \\
\hline$(\mathrm{T} 1)$ & & $f \Omega$ & ל & 0033 & $c 0$ & $d i$ & 3 & $\operatorname{lot}^{-1}$ & \\
\hline $\mathrm{S}+\mathrm{a}$ & $c 0.00$ & TU.UO & .00 & c0.33 & C0.007 & au.00 & Co.03 & eu.00 & 3003 \\
\hline
\end{tabular}

* - similar characters means there is no significant difference between treatments; a - best among the treatments (The highest value compared to the other treatments)

* - podobné znaky znamenajú, že medzi postupmi nie je žiadny významný rozdiel; a - najlepšie z opatrení (Najvyššia hodnota v porovnaní s ostatnými postupmi)

Tabulka 3 Vplyv vzájomného pôsobenia času výsadby, zmesí pôdnych substrátov a typov odrezkov na pozorované charakteristické vlastnosti Vitex agnus-castus L.

(1) pozorované charakteristické vlastnosti, (2) čas výsadby, typy odrezkov a pôdne substráty, (3) počet vetiev (pc), (4) priemerný počet listov ( $\mathrm{pc}$ ), (5) priemerná dlžka výhonkov $v \mathrm{~cm}$, (6) počet koreňov ( $\mathrm{pc})$, (7) priemerná dlžka koreňov $v \mathrm{~cm}$, (8) čerstvá hmotnost výhonkov v g, (9) čerstvá hmotnost' koreňov v g, (10) suchá hmotnost' výhonkov v g, (11) suchá hmotnost' koreňov v g 
on the roots what agrees with Garnar and Hatcher (1955) who proved that the rooting rate is decreased in hardwood cuttings planted in the sand and using the semi-hardwood cuttings increases the length of shoots as well as it increases the number of roots, the root length and the fresh weight of shoots and roots. All of these differences were significant.

Table 3 shows that planting in the sand by using semihardwood cuttings during (T1, T2) as well as planting in the sand + peat moss and using the same kind of cuttings during the T2, led to an increase in the number of branches and the differences were significant compared to other treatments. The addition of organic matter in the form of peat can improve the physical status of soil for better root development because of increased aeration in the media (Al-Menaie et al., 2010), while planting in T2 increased the number of leaves in the soil mixture (sand + peat moss) in semi hardwood cuttings what agrees with Rasul et al. (1984). Planting in (spz) in T1 due to increasing in root numbers, while fresh and dry weight increase in T2 by using (spz), sp) and (sz) in semi hardwood cuttings. Effect of media may be due to the difference between them in their ability to retain a sufficient quantity of water for the processing of the cuttings and to divert excess water and ventilation rate.

\section{Conclusion}

Planting in the first period (T1) causes increase in root numbers and root length, increase in fresh and dry weight has been observed in the second period of planting. Planting in the sand media using semi hardwood cuttings $(\mathrm{m})$ causes increase in number of branches and leaves, fresh weight, root numbers and root length. So we suggest that planting in the first period and using semi-hardwood cuttings is more advisable.

\section{Acknowledgement}

Paper was elaborated thanks financial supporting by grant project KEGA No.020SPU-4/2011 of Ministry of Education, Science, Research and Sport of the Slovak Republic, and project COST TD1106-UAE.

\section{Súhrn}

Výskum vegetatívneho rozmnožovania Vitex agnus-castus L. bol realizovaný na výskumných plochách Polnohospodárskeho inštitútu Univerzity Salahaddin, v kontrolovaných podmienkach (fóliovník) $\mathrm{v}$ dvoch sledovaných obdobiach (letné obdobie: 26. 5. 2008 - 2. 9. 2008 a zimné obdobie: 15. 1. 2009 - 28.4. 2009). Skúmaný bol vplyv rôznych pôdnych substrátov (piesok - piesok; riečny piesok - piesok; rašelina - piesok; riečny piesok a rašelina). Použili sme dva druhy stonkových odrezkov (odrezky z polotvrdého dreva "m“; odrezky z mäkkého dreva „a"). Štatistická analýza vychádza z experimentálneho projektu (Complete Randomized Design CRD) $\mathrm{s}$ tromi opakovaniami. Výsledky získané prostredníctvom CRD boli následne porovnané s výsledkami získanými Duncanovým testom na úrovni 0,05. Výskumom sme dokázali, že výsadba v druhom sledovanom období (T2) vykazuje nárast počtu vetiev a počtu listov, kým výsadby $v$ prvom sledovanom období (T1) vykazujú zvýšenie počtu a dížky koreňov a výsadby v druhom sledovanom období (T2) vykazujú zvýšenie hmotnosti biomasy, ako aj hmotnosti sušiny. Výsadba do pieskových substrátov za použitia odrezkov z polotvrdého dreva $(\mathrm{m})$ spôsobuje nárast počtu vetiev, listov a koreňov, zvýšenie čerstvej váhy a predĺženie koreňov.

Klúčové slová: Vitex agnus-castus, rozmnožovanie rastlín, odrezky, pôdne substráty

\section{References}

ALKUTUB, M. A. - NABIL, B. - MUNA, KH. 1997. Effect of some rooting media and concentrations of IBA hormone in Jasmine rooting. Damascus University. In: Journal of Agriculture Sciences, vol. 13, 1997, p. 67-77.

AL-MENAIE, H. S. - AL-ROGOM, O. - AL-SHATTI, A. - SURESH, N. 2010. Evaluation of the growth performance of Cassia nodosa and Cassia fistula L. Seedlings using different potting mixtures. In: Academic Journal of Plant Sciences, vol. 3, 2010, no. 1, p. 33-36.

ELGIMABI, M. N. E. 2008. Effect of season of cutting and humidity on propagation of Ixora coccinea. In: Advances in Biological Rereach, vol. 2, 2008, no. 5-6, p. 108-110.

ALRAWI, K. H. M. - KHALAF, A. M. 1980. Agricultural experiments design and analysis, Ministry of Higher Education and Scientific Research, the University of Mosul.

GARNAR, R. J. - HATCHER, E. J. 1955. The influence of scurce and growth substance on the behavior of apple and plum cutting. In: Journal Hort. Sci., vol. 30, 1955, p. 116-128.

MAHFOUD, M. - MAKHOUL, J. 2006. Effect of planting time and different concentrations of IBA in rooting hardwood cuttings of Kiwi Actinidia chinesis. In:Tishreen University Journal for Studies and Scientific Research - Biological Science, vol. 28, 2006, no. 3.

MOHYELDEEN, N. E. E. 2009. Improvement of Propagation by Hardwood Cuttings With or Without Using Plastic Tunnel in (Quisqualis indica). In: Advances in Biological Research, vol. 3, 2009, no. 1-2, p. 16-18. RASUL, R. H. - SHAKR, M. - KHALEED, H. 1984. Studies on the growth and flowering of Buddleia variables and effect of planting time and growth media in propagation of matured cuttings. In: Iraq Journal for Agricultural Sciences - Zanko, vol.2, 1984, no. 1, p. 123-139.

ROBBINS, J. A. - EVANS, M. R. 2009. Growing media for container production in green house or nursery. In: Agriculture and Natural Resources. http://www.uaex.edu.

SIMA, N. - SHAHRBANO, O. - ALI HAERI, R. - GHOLAM, R. A. 2007. The Effects of Vitex agnus-castus extract and it's Interaction with Dopaminergic system on LH and Testosterone in Mali Mice. In: Pakistan Journal of Biological Sciences, vol. 10, 2007, no. 14, p. 2300-2307.

WELCH, W. C. 2008. Vitex or Chaste tree (Vitex agnus-castus). Texas AgriLife Extension Service. Hote Vpoaculture.

WELLS, J. S. 1985. Plant Propagation Practices. American Nurseryman Publishing Co., Suite 2100, 77 W. Washington St. Chicago, IL. 60602-2904

\section{Contact address:}

Maryam I. S. Alkurdi, Slovak University of Agriculture in Nitra, Faculty of Horticulture and Landscape Engineering, Department of Garden and Landscape Architecture, Tulipanova street No. 7, 94901 Nitra, Slovak Republic, e-mail: maryam2000salih45@gmail.com; Sabiha S. Mustafa, Horticulture and Forestry Department, Agriculture College Salahaddin University, Iraq Kurdistan Region-Erbil, e-mail: mustafasabiha@yahoo.com; Ján Supuka, Slovak University of Agriculture in Nitra, Faculty of Horticulture and Landscape Engineering, Department of Garden and Landscape Architecture, Tulipanova street No.7, 94901 Nitra, Slovak Republic, e-mail: Jan.supuka@uniag.sk 